Mobilitäten / Mobilities 


\title{
Seeking Security under the Yellow Flag. Disease as a Tool of Colonial Discourse and Practice in the British West Indies (ca. 1790-1810)
}

\author{
Karina Turmann
}

\section{Abstract}

Along with European colonialism in the Americas, a plethora of diseases spread on large scales across the Atlantic. The mode of warfare, high mobility and the human invasion and transformation of nature promoted the emergence and dissemination of "tropical diseases". At a time when the actual paths of infection, contagion or vectors were not known - or not verifiable - Eurocentric pathogenesis of an illness was based on concepts such as miasma theory. In the process of developing, modifying, and using medical theories about these unknown disorders, colonialists claimed that Africans had a certain immunity to diseases of hot climates. This paper examines the colonial situation at the end of the 18th century in which discussions about the "dangerous tropics" highlighted the physical conditions of European soldiers to advocate for the military deployment of enslaved men. The debate involved the claim that the conquest and protection of the Caribbean colonies, and thus economic progress, was at risk because soldiers, particularly mariners, were getting sick; the scientific interpretation of a climate-induced susceptibility to diseases; and the recruitment of "slave regiments", which fostered new and competing perceptions of security. An analysis of these different threads shows how theories of a race-specific susceptibility to disorders based on climatic adaption was part of colonial concepts and imperial thought. These strands corresponded with arguments aimed at legitimising the enslavement of people from Africa in the first place.

\section{Introduction}

"Narrative is radical, creating us at the very moment it is being created." 1

In the wake of European colonialism in the Americas, a plethora of diseases spread on large scales across the Atlantic. The dominant mode of

1 Morrison, Toni (1993): Nobel Lecture. https://www.nobelprize.org/prizes/literatur e/1993/morrison/lecture, 18.07.2021. 
warfare, high mobility, and the human invasion and transformation of nature led to epidemics and characterised the "struggles for Empires in the American Tropics" (McNeill 2004). Many of these illnesses would nowadays be classified as 'tropical diseases' because of their primary prevalence in tropical or subtropical regions. Although this term is a rather modern construct and influenced by 19th-century exoticism, European medicine linked "diseases of hot climates" to particular geographical locations and environmental conditions even long before the 19th century (cf. i.a. Arnold 2003 and 2015; Eckart 2005; Harrison 2002; Seth 2018). European medical science in the 18th centuries was still largely lacking the knowledge about contagion or vectors, such as insects that survive and reproduce preferably under warm and humid conditions. At a time when actual paths of infection were not known - or not verifiable pathogenesis of a disease mainly based on concepts such as the miasma theory, stating that "bad air", arising from rotten soil, organic material, and similar caused diseases. ${ }^{2}$

The process of gaining, modifying, and using knowledge about those enigmatic disorders included the Eurocentric claim that people from Africa had a certain immunity to "diseases of hot climates". These medical theories linked sickness to the atmospheric setting - that is to say, to temperature, humidity, and the elements - and concluded that being accustomed to hot and humid conditions implied a lower (physical and mental) vulnerability or susceptibility to locally prevalent diseases, e.g. in the Caribbean. Within the colonial discourses about health and diseases in tropical regions, these assumptions had implications on several levels, including the construction, hierarchisation, and perpetuation of physical differences as well as the justification of the slave trade and slavery in a period of increasing abolitionist movements against those institutions. Moreover, British economic and political interests took advantage of those medical conclusions: At the end of the 18th century, despite economic downturns and the shift of British imperial attention to other regions, the colonies in the West Indies were highly valuable to the British Empire in light of competition among the European Empires and their forces on the spot. Ongoing attempts to exploit more territories in the area, substantial imports as well as the continuing export of taxable commodities and goods from and to the islands secured the Empire's competitiveness and

2 Early "contagionist theories" like the one of Girolamo Fracastoro in the 16th century, failed to gain acceptance among the wider scientific community and the general public (Karamanou et al. 2012, p. 59). 
contributed to maintaining the capitalistic system. The British notion of "security" in this context concerned the military's assignment to protect and expand imperial power in the region, accompanied by the controversy about the soldiers' physical condition (cf. The Fifth Report of the Board of Health 1805).

This paper examines the colonial process around 1800 in which debates about the "white man's graveyard" (Convertito 2011, p. 2) referred to the above-named medical theories to advocate for the military deployment of enslaved men by highlighting the following aspects: The British claim that conquest and protection of the Caribbean colonies was at risk because soldiers, particularly mariners, were getting sick. Hence, the scientific interpretation of a climate-induced susceptibility to diseases, followed by a move to recruit 'slave regiments', which brought about new and competing notions of security problems against the backdrop of an intended colonial order.

Considering that diseases were more a rule than an exception throughout history, it is necessary to take into account how colonialism directly exacerbated the threat to the physical health of different groups. Soldiers and slaves were exposed to a permanent state of personal insecurity. Yet, while the supposed protection of the former was brought to the fore although military strategy even reckoned with infections among the troops (cf. Buckley 1979, p. 10) - the alleged resilience of the latter served as an instrument for advancing the British colonial agenda. The analysis of the above outlined process can therefore help to understand how diseases facilitated certain developments within colonial discourse in terms of not only mystifying and exoticising particular regions but of promoting stigmatising ideas of "race" that implicated security related triggers (cf. Hall/ McClelland 2010; Hogarth 2017). In the debate about deploying slave regiments proponents of this strategy reinforced the same reasoning that was used to argue against the abolition of the slave trade or slavery in general. They claimed that a black body, in their understanding meaning an African or Creole body, was better suited for working in hot climates and less vulnerable in terms of its ability to tolerate heavy labour and diseases.

One of the reasons why the stigmatisation of skin colour became firmly established in colonial thinking can be found in the contemporary blurring applications of terms like being "African", being "black", or being "enslaved". Within the debate on the question of deploying coloured soldiers their status was crucial in the emergence of racialised preconceptions that fuelled fears of this group of weaponed slaves, even though there already existed a long tradition of deploying non-enslaved coloured 
soldiers. ${ }^{3}$ Furthermore, tropical diseases certainly threatened all human beings in the Caribbean at that time. But in terms of mortality - irrespective of its causes and aggravated by the cruelty of enslavement itself - that of enslaved people outnumbered that of the non-enslaved and white by far. "If white mortality was appalling then, if anything, enslaved mortality was worse" (Lockley 2020, p. 15; see also Convertito 2011). Contemporary Eurocentric perceptions, and not least historiographic tradition of the "appalling white mortality", which cannot be examined in detail here (for this critique, see e.g. Convertito 2011; Lockley 2020; Nash 2014), implicated a colonial body of knowledge that reveals how certain security narratives and measures constructed these continuing ideas of difference, and often disregarded the impact of colonialism itself.

\section{Locating the Threat: Soldiers and Sickness}

As Benedikt Stuchtey and Andrea Wiegeshoff (2018, p. 322) point out, "the British Empire acted as producer of security and insecurity at the same time, with these two qualities being closely intertwined". Siege wars in the Caribbean were always fought under risky conditions and against the backdrop of fluctuating political and military spheres of influence, the ever-present danger imposed by privateers and other unpredictable circumstances at sea, and the numerous different preconditions and occupations of the diverse islands. Colonial wars constantly claimed the lives of recruits, resulting in more and more men having to be sent to the West Indies, most of whom were inexperienced with working in hot and humid environments. Consequently, even more of them fell sick during their time in service. Moreover, as the (ordinary) soldier was often recruited from poorhouses or prisons, his state of health was comparably poor to begin with (Peters 1800, p. 22; also cf. Buckley 1979, p. 11; Geggus 1979, p. 52; McNeill 2010, p. 352), a circumstance that nourished the colonial narrative of the dangerous tropics. Nevertheless, particular inherent factors worsened the situation of troops deployed in the West Indies:

3 For a detailed and elaborate study of the West India Regiments that considers the "concept of blackness without the paradigm of slavery", see Lockley 2020. - If "black" and "white" as a dichotomous terminology is used here it depicts historical Eurocentric ascriptions that generally referred to colonised Africans or people of African descent and colonising Europeans, and is obviously a simplification considering the wide range of ethnic and social diversity and heterogeneity in the region. 
One of the most wearing problems for Europeans when waging war in tropical regions was undoubtedly the heat, intensified by inappropriate clothing and lifestyle. The lack of preconditions for adequate body hygiene, and ill-fitting uniforms made of dense materials like flannel, permanently encrusted with sweat, caused excessive heat accumulation. The traditionally tight-fitting, heavy woollen jackets of the British infantry were not abolished entirely, but for some expeditions flannel was replaced by linen. Not until the 1790s leather collars and gaiters were exchanged for scarves; airy cotton trousers and pith helmets were gradually implemented; the red jackets were shortened but never entirely removed. All in all, the best protection was not to be exposed to the sun but working in the midday heat could not always be avoided. The circumstance of troops being undermanned led to a continuous lack of sleep. In addition, the soldiers often went to bed in wet clothes. Frequent dysentery entailed a permanent undersupply of nutrients. A diet mainly based on salted meat together with persistent heat, brackish or contaminated drinking water, freewheeling consumption of spirits, and the overall setting that put a heavy strain on mental health all combined to create what some observers have described as the crippling situation of a soldier in the tropics (Duffy 1987, p. 356; Geggus 1979, p. 52f.).

The precarious situation of military personnel in the West Indies was a product of European colonialism, but the problem of the bad state of health provided an alternative scheme for the colonial narrative. For those in search of an explanation for why so many battles were unsuccessful the menace of tropical diseases was a perfect point of attack. Once the problem was framed in this way, generating and applying medical knowledge became crucial in the discussion about what to do to secure the colonies and their economic value. Early medical investigations revealed a connection between unhealthy lifestyles and the susceptibility to diseases within the troops. Elliot Arthy, a surgeon in the African and West Indian merchants' service, blamed the dirty environment on ships and barracks and excessive alcohol consumption to be the cause of the soldiers' "state of intoxication". In most cases, there was no time to clean the ship properly or to ensure a sufficient supply of fresh air between loading and unloading (Arthy 1798, p. 56ff.). Yet, most of the medical reports did not attribute sickness to being aboard a ship but to the time spent ashore. In June 1795, a yellow fever epidemic on the island of Martinique claimed many lives among the troops, which is why the Leeward Island squadron was kept at sea. The attempted quarantine was not intended to isolate the sick soldiers in order to protect the people ashore but to keep the mariners away from the "noxious" coastal areas. This strategy of controlling the disease did not 
work for long due to frequent commuting between the different islands, especially Dominica and Guadeloupe. The fever spread rapidly (Gillespie 1800, p. 15ff.).

Reflecting on the connection between seashores and sickness, Arthy claimed that the mode of troop recruitment was part of the problem caused by siege wars in the West Indies. The so-called "goodrun home sum" - a one-off amount in addition to the usual monthly wages was paid for service on a ship that returned home from the Caribbean. He blamed this bonus for regularly occurring epidemics: Since many mariners stayed on land to keep watch for the best chance of hiring on to a long-distance mission from the colonies back to Britain, they were permanently exposed to health-threatening environments on shore and inland (we know today that these areas provided good breeding grounds for mosquitoes), significantly increasing the risk of getting sick compared to staying on board (Arthy 1798, p. 31). Explanations and recommendations concerning the health of British servicemen increasingly focussed on the conditions of the soil and air, which were subsumed under the category of what the contemporaries called "the climate".

\section{Scientific Interpretations: Bodies and the Climate}

Among the considerable number of expeditionary troops that were sent to the British West Indies, most of the soldiers had no experience of serving in tropical regions. This favoured the development of epidemics, especially when the men reached the islands during the season when mosquito populations and thus virus transmissions peaked. Leonard Gillespie, a physician and surgeon in West African and West Indian squadrons, attributed sickness on ships to the autumn months, when the air was humid, stagnant, and heavy rains and thunderstorms caused a certain despondency among the sailors. He noticed masses of annoying insects in the air but did not associate them with the spread of diseases (Gillespie 1800, p. 34). Many unknown animals — and insects in particular — had yet to be studied and categorised to explain their impact on humans and the environment. Most of these tiny creatures were not only obscure and bothersome in the European view but also frightening and disgusting, like cockroaches that pinched arms and legs at night or sand fleas that burrowed under toenails and caused severe itching (cf. Buckley 1998, p. 38). Even so, early theories that linked the presence of insects to the prevalence of diseases seemed inconceivable to most medics. Hence, the colonial concern of preserving the health of military personnel in the Caribbean at the end of the 18th 
century produced numerous publications on the prevention of various diseases at sea and in tropical regions (e.g., Bell 1791; Henderson 1795; Jackson 1808; Moseley 1787; Pinckard 1806; Smyth 1799) that referred to the detrimental impact of a tropical climate to white Europeans.

While residing in Barbados in the 1750s, the English physician William Hillary claimed to see a connection between the outbreak of fever and the unsuitability of a white body to the prevailing climate. Particularly in hot and dry months, interrupted by heavy rains, numbers of fever cases increased, most of which might have been yellow fever. Nevertheless, he believed it to be highly unlikely that seasonal or weather-related variations caused the fever outbreak. He was also very critical of the contagionist theory, as he had never noticed a direct transmission among human beings (Hillary 1766, p. 145f.). Later medical records describe similar observations but also refer to those early perceptions. Elliot Arthy found it hard to explain why the yellow fever broke out on board of the Pilgrim one week after the ships' departure from the west coast of Africa. Drawing on his experience, he was a firm believer in the theory of onshore infection, yet scrutinising the putrid milieu aboard. This notion was confirmed when, on the homeward journey, the fever did not begin to rage among the crew again until a few weeks after their departure. He claimed that the fertile nature in warm climates brought about fine evaporations (effluvia) produced by the interaction of soil, living beings, the sun, and the rain. This amalgam would arise, spread in the air, and connect with moisture created by the heat of the sun. He himself had smelled the "fumes" and considered them to be harmful to human health. If people inhaled them, they would cause the "Bilious and Yellow Fever", particularly in those who did not grow up in the West Indian region and were not used to the climate, or those bodies that were weakened by illness, fatigue, poor lifestyle, mental restlessness, drunkenness, or work under the sun at noon (Arthy 1798, p. 2-4).

As the common understanding of infection on ships included the warning that a disease could be carried from the muddy soils to the ships by offshore breezes at night, preventive measures recommended rubbing salt water all over the body in the morning and evening. This strategy made an impact in the cases of two ships in North American harbours while hundreds of other seamen died in the same region (Directions to Mariners, who Trade to the West-Indies, to Avoid the YELLOW FEVER 1799, p. 754). Although the actual principle of this prophylaxis was not known, it proved effective, as salt water prevented mosquito bites and quarantine stopped the transmission. That is why William Turnbull, a fellow of the Medical Societies in London and Edinburgh and surgeon in the Navy, 
emphasised that the prevention of diseases at sea must include measures concerning the air, cleanliness, clothing, diet, exercise, and discipline. He considered the air at sea to be purer than on shore and described the latter as follows: The "land air is in many situations rendered particularly noxious, by the different impregnations it receives from woods, and morasses, as well as by other matters producing dangerous effluvia. These, though in the colder climates are less to be dreaded, acquired a particular virulence when acted upon by heat. Hence the mortality that has been known to arise in the West Indies, and other warm climates [...]" (Turnbull 1806, p. 4). But he did not stop at hierarchising the different spatial dimensions that, in his view, accounted for the prevalence of diseases. He also gave a detailed ranking of the (descending) susceptibility to yellow fever based on age, gender, ethnicity, and social or professional background:

1. "Sailors, more especially the robust and young: those least accustomed to the climate; and those most given to the drinking of new rum.

2. Soldiers, especially recruits lately from Europe; and the most intemperate.

3. White males in general lately arrived; more especially young men from Europe.

4. All other white males, more especially the lower classes; and of them the most intemperate; those debilitated by recent sickness.

5. White females, more especially those connected with the shipping; and those lately from Europe.

6. People of colour, from Mustees to Cabres.

7. Negro-men, more especially sailors and porters.

8. Negro-women, more especially house-wenches.

9. Children, more especially those of colour" (Turnbull 1806, pp.170f.).

His model ranks the susceptibility to yellow fever by reference to categories that were designed with an eye to the allocation of people to serve the interests of the Empire in different domains most efficiently, for instance, the placement of an enslaved person in a working environment according to their physical adaptability. Classifications were not only adapted for medical reasons but also to address other security issues associated with the putative physical unsuitability of Europeans in the colonies. Quarantine measures (in line with the contagion theory) were even opposed because it "was far easier and more palatable to blame an epidemic on the 'filthy' living conditions of imperial subjects than it was to accept responsibility for spreading (or stopping) contagions that were not the responsibility of indigenous people. [...] The anticontagionist rhetoric of demolishing a fetishistic belief in contagion runs together with 
an imperial discourse of 'enlightening' colonized peoples" (Chase-Levenson 2020 , p. 222). These artificial hierarchies appeared beneficial for the promotion of a colonial order in many respects, not least in providing arguments in support of the need for a "civilising mission", which was initiated on a large scale around 1800 (cf. Osterhammel 2010, p. 1175f.). Reference to such hierarchies can also be found in later colonial contexts. ${ }^{4}$ In the period considered here, they served as the argumentative foundation for the deployment of slave regiments.

\section{Medical Measures and the Deployment of Slave Regiments}

European medical interpretations and treatments of the time turned out to be mostly inefficient in fighting the physical ailments in the Caribbean. When we read these medical reports today, although they refer to certain conditions, it becomes clear that the diagnoses of malaria, typhus, yellow fever, or other diseases were not very precise and often confounded. The Royal Navy equipped many of their ships "with a medicine box, out of which the captain or his mate dispense[d], as they conceive[d], relief to the sick when at sea, and wherever the assistance of a surgeon [could] not be obtained." Those boxes were usually filled by druggists with a rather poor knowledge of tropical diseases (cf. Arthy 1798, p. 87). But not just medical laymen used common medicinal products such as emetics or mercury; surgeons and physicians also relied on them and complemented them with other current treatments. One of the effective remedies against prevailing types of fever, the cinchona bark, was not always sufficiently available during the Caribbean siege wars in the late 18th century. Extensive research was done on available surrogates, but scientists questioned their efficacy. In many cases the classical European treatments were dangerous and even deadly. Bloodletting and other traditional therapies can be assumed to have further aggravated health deficiencies. The necessity of different strategies to react to the threatening diseases became apparent. Consequently, military strategies entailed knowledge about climatic conditions that had emerged from former experiences in the tropics.

During the besiegement of Saint-Domingue in the 1790s, the redeployment of troops to higher mountainous areas proved effective at first. Death rates in the mountains were below those in coastal areas or the flatlands

4 Cf. Florian Neiske's chapter on the relationship between difference and (in)security, using the example of European seafarers in colonial Calcutta, in this volume. 
(Buckley 1998, p. 22). The British troops relocated from the outposts to the mountains, new barracks were built above the harbours and swamps were drained. Yet, the numbers of ill soldiers remained high overall, which can be explained by the frequency of different diseases. The numbers of sick people in Port-au-Prince were soaring as the hospital was located next to a swamp. General Simcoe urged his soldiers to exercise in fresh air, but moreover he replaced some of the posts with "acclimatised residents" of the island (Geggus 1979, p. 52). The concept of acclimatisation was a principle of surviving in hot climates, but moreover it became a feature of physical advantage and eventually a colonial tool to improve chances of success in times of military and political instability. Nevertheless, it could not undermine the dichotomy that had been created between the different adaptability of black and white bodies.

The inefficiency of European medicine and infection prophylaxis in combination with the colonialists' aforementioned experiences and medical perceptions led military authorities to conclude that sending more and more white troops was not an effective strategy in the long run; and critics back in Britain saw it as a waste of human resources. Commanding officers considered to train a permanent slave regiment that would be "resistant" to the prevailing heat and diseases. In addition, it was thought to be easier to take advantage of this group than to hire free coloured locals or to take the detour of recruiting via Europe. That way, they argued, French troops - who already commanded a significant number of black soldiers in this area - could also be met on equal footing (Vaughan to Dundas 1794). The proposition was rejected because of the constant fear of revolts and in response to indignation on the part of the planters. Permanent slave regiments under the control of the British government expanded the government's central agency, and the West India Committee viewed this as an unwanted intervention with respect to their administrative autonomy. Although the colonial slave owners were aware that a strategy to counteract the shrinking numbers of soldiers was required to secure their properties, they also needed an enslaved workforce to keep up productivity on their plantations, particularly in the face of the imminent possibility of an abolition of the slave trade (West India Committee 1795). When the idea of incorporating a corps of enslaved soldiers into the regular British regiments emerged in 1795, the colonial legislature in Britain was alarmed. Representatives of traders and plantation owners supported opposition to this proposal in Parliament but eventually approved of a plan for non-regular recruitment (Lockley 2020, p. 19). According to this plan, temporary provincial units could be drawn from the traders' and planation owners' group of slaves in an emergency, but the enslaved soldiers would 
remain under their owners' possession. This group would be deployed exclusively in the area and return to their owners after the mission - a compromise to maintain the colonial order. More critically still, the status of an enslaved person as a regular member of the British Army disrupted the imperial notion of social classification (Duffy 1987, pp. 363f.; see also Wheeler 2000), because it was unclear how to deal with the fact that the enslaved - despite the attempts to implement measures to improve their legal status - had virtually no rights at all. (cf. Buckley 1979, pp. 2ff.; Lockley 2020, p. 15).

These competing notions of security needs and measures exacerbated the way in which concepts of difference became racialised and classicised. The susceptibility to diseases turned into a continuing issue in the discussions about expeditions and military missions and intersected with the debates on the abolition of slavery and the slave trade, and the patronising ideas of a civilising mission. Drawing on medical reports, the abolition opponents as well as the sceptical voices within the military debate assumed that an aggressive and confrontational, ultimately uncontrollable behaviour was part of the "black character", and would be reinforced by enslavement. Allegedly resulting from growing up in hot climates these attributes were said to have values and risks regarding colonial projects. Bryan Edwards, a politician and strong supporter of the slave trade, bolstered this assumption by considering the example of the "Coromantee", the English term for enslaved people of Akan descent from the Gold Coast (in modern Ghana). There were not only many of them, but, according to the planters, they also met the physical requirements for good, robust workers. Moreover, and this was the colonisers' decisive perception of their disposition, they proved to be rebellious. Therefore, the Coromantee were seen to be "aggressive", too. Frequent insurrections under their guidance or in their large presence had taken place, and led to the perception of a conspiratorial energy. This rebelliousness was not least rooted in the Coromantee's ability to organise as a group on account of sharing a common language (Akan). Since many of the enslaved Coromantee were said to have been slave owners themselves, or belonged to the elites in their homeland, sceptics of deploying slaves argued that it would not be surprising were they to exact revenge on their own owners (cf. Barbados Legislature 1797; Edwards 1789, p. 152ff.). This prejudice provided arguments for enslaving, punishing while enslaved, and 'civilising' Africans and their descendants, and directly addressed the fears of the colonists, not least in the context of the controversy about armed slaves; and it had further long-term effects: When it was later discussed how to proceed in the event of an emancipation of the enslaved, this perception led to emphasising the 
dangers of their immediate release (cf. e.g., Speeches of Messrs. Thomson $\&$ Borthwick, on the Question of Colonial Slavery 1833, p. 16 and 20). During the period considered here, images of the rebellious and aggressive black man were instrumentalised to prevent enslaved people from being sold to and deployed in the military. Military, economic, and political security efforts were blurred here, but they depict the parallel lines of argument that harnessed the concept of a "black body" but also a "black character" for their colonial purposes, far beyond the range of plantation work, and the discussion about slavery and the slave trade.

\section{Summary and Discussion}

As we have seen above, the security lens enables us to unravel not only the highly entangled histories of different colonial ambitions but also their impact in terms of the creation of more specific notions of heterogeneity. The military's task of conquering and defending the Caribbean islands to extend the British Empire's sphere of influence and increase its economic yield involved the need to protect those territories, and the plantations in particular, to ensure their colonial economic value. And this is how the term and notion of "security" directly appears in the sources: the aim to secure the tropical colonies was framed. Interpretations and measures in reaction to the threat of diseases applied the same heuristic basis of European knowledge - that is, miasma theories and concepts of climate-induced susceptibilities to diseases - to different colonial situations and had to deal with the fact that allegedly innovative European medicinal practices proved to be not only ineffective but, in many cases, even destructive.

There was no indication whatsoever of an inherited black immunity in the context of most diseases (see also Espinosa 2014). The reasoning of a race-specific susceptibility to disorders based on climatic adaption was contradicted by the high rates of illness and mortality among enslaved black people, that put the planters into an argumentative dilemma. Advocates of slavery used the same allegation of immunity and physical strength to maintain the enslavement of Africans. And since they faced abolitionist and ameliorationist movements that pressed for measures to improve the conditions of enslaved people in the West Indies, the slaveholders and their supporters avoided any explanations that tied diseases and death to the physical neglect of the slaves or any form of violence against them. In line with this, all kinds of theories surfaced to account for the high levels of sickness on plantations, and most of these theories had an extremely racist and misogynist impetus and furthered condescending imperial ideas 
of difference (cf. Seth 2018). The deployment of slave regiments was based on colonial calculus and imperial thought, identical to the arguments that legitimised the enslavement of Africans in the first place, as a result of othering and downgrading people of African descent and equating being black with being enslaved. Another dilemma of British colonialism in this respect was that it created new security-related notions of certain dispositions that argued against weaponing enslaved people. What is more, this controversy created stigmata, and shaped ideas of blackness that were deeply burned into later forms of imperialisms and their aftermath.

\section{Works Cited}

Arnold, David John (ed.) (2003): Warm Climates and Western Medicine. The Emergence of Tropical Medicine, 1500-1900. 2nd ed. Amsterdam: Rodopi (The Wellcome Institute Series in the History of Medicine, 35).

Arnold, David John (2015): The Tropics and the Traveling Gaze. India, Landscape, and Science, 1800-1856. Seattle: University of Washington Press (Culture, Place, and Nature).

Arthy, Elliot (1798): The Seaman's Medical Advocate, or, an Attempt to Shew that Five Thousand Seamen are, Annually, During War, Lost to the British Nation, in the West-India Merchants' Service, and on-Board Ships of War on the WestIndia Station, through the Yellow Fever, and Other Diseases and Means, from Causes which, it is Conceived, are Chiefly to be Obviated, and Unconnected with the Misfortunes of War or Dangers of the Seas: Illustrated by Cases and Facts: Most Respectfully Submitted to the Consideration of the British Senate, the Right Honorable the Lords Commissioners of the Admiralty, the Admirals of Fleets, and the Commanders of Ships of War, on the West-India Station, the West-India Merchants, and the Commanders of West-India Merchantmen. London.

Barbados Legislature (1797): b. West Indies and South America. iv. Windward and Leeward Islands. Commander-in-Chief, West Indies. The National Archives (United Kingdom), WO 1/86.

Bell, John (1791): An Inquiry into the Causes which Produce, and the Means of Preventing Diseases among British Officers, Soldiers and Others in the West Indies. Containing Observations on the Action of Spirituous Liquors on the Human Body. London.

Buckley, Roger Norman (1979): Slaves in Red Coats. New Haven/London: Yale University Press.

Buckley, Roger Norman (1998): The British Army in the West Indies. Society and the Military in the Revolutionary Age. Gainesville, Fla: University Press of Florida. 
Chase-Levenson, Alex (2020): The Yellow Flag. Quarantine and the British Mediterranean World, 1780-1860. Cambridge: Cambridge University Press (Global Health Histories).

Convertito, Coriann (2011): The Health of British Seamen in the West Indies, 1770-1806. Dissertation. Exeter: University of Exeter (Maritime History).

Directions to Mariners, who Trade to the West-Indies, to Avoid the YELLOW FEVER (1799). In: The Gentleman's Magazine: and Historical Chronicle, Jan. 1736-Dec. 183369 (3), p. 754.

Duffy, Michael (1987): Soldiers, Sugar, and Seapower. The British Expeditions to the West Indies and the War Against Revolutionary France. Oxford: Clarendon Press.

Eckart, Wolfgang Uwe (2005): From Questionnaires to Microscopes: Founding and Early Years of the Hamburg Institute of Nautical and Tropical Diseases. In: Stuchtey, Benedikt (ed.): Science across the European Empires, 1800-1950. Oxford: Oxford University Press (Studies of the German Historical Institute London), pp. 309-328.

Edwards, Bryan (1789): The History Civil and Commercial, of the British Colonies in the West Indies. To which is Added, a Historical Survey of the French Colony in the Island of St. Domingo. London.

Espinosa, Mariola (2014): The Question of Racial Immunity to Yellow Fever in History and Historiography. In: Social Science History 38 (3-4), pp. 437-453.

Geggus, David (1979): Yellow Fever in the 1790s: The British Army in Occupied Saint Domingue. In: Medical History 23 (1), pp. 38-58.

Gillespie, Leonard (1800): Observations on the Diseases which Prevailed on Board a Part of His Majesty's Squadron, on the Leeward Island Station, Between Nov. 1794 and April 1796. London: G. Auld.

Hall, Catherine/McClelland, Keith (Eds.) (2010): Race, Nation and Empire. Making Histories, 1750 to the Present. Manchester: Manchester University Press (UCL/Neale Series on British History).

Harrison, Mark (2002): Climates and Constitutions. Health, Race, Environment and British Imperialism in India, 1600-1850. New Delhi: Oxford University Press.

Henderson, Stewart (1795): A Letter to the Officers of the Army under Orders for, or that May hereafter be Sent, to the West Indies, on the Means of Preserving Health, and Preventing that Fatal Disease the Yellow Fever. London.

Hillary, William (1766): Observations on the Changes of the Air and the Concomitant Epidemical Diseases, in the Island of Barbadoes: To which is Added a Treatise on the Putrid Bilious Fever, Commonly Called the Yellow Fever and such Other Diseases as are Indigenous or Endemial, in the West India Islands, or in the Torrid Zone. London.

Hogarth, Rana A. (2017): Medicalizing Blackness. Making Racial Difference in the Atlantic World, 1780-1840. Chapel Hill: University of North Carolina Press. 
Jackson, Robert (1808): An Outline of the History and Cure of Fever, Endemic and Contagious: More Expressly the Contagious Fevers of Jails, Ships, \& Hospitals, the Concentrated Endemic, Vulgarly Called the Yellow Fever of the West Indies: To which is Added, an Explanation of the Principles of Military Discipline \& Economy, With a Scheme of Medical Arrangement For the Army: And a Refutation of the Strictures Made by the Late Dr. Currie on that Part of the Work which Relates to the Affusion of Cold Water on the Surface. Edinburgh.

Joseph, Michael (2017): Military Officers, Tropical Medicine, and Racial Thought in the Formation of the West India Regiments, 1793-1802. In: Journal of the History of Medicine and Allied Sciences 72 (2), pp. 142-165.

Karamanou, Marianna/Panayiotakopoulos, George/Tsoucalas, Gregory/Kousoulis, Antonis A./Androutsos, George (2012): From Miasmas to Germs: A Historical Approach to Theories of Infectious Disease Transmission. In: Le Infezioni in Medicina 20 (1), pp. 58-62.

Lockley, Tim (2020): Military Medicine and the Making of Race. Life and Death in the West India Regiments, 1795-1874. Cambridge: Cambridge University Press.

McNeill, John Robert (2004): Yellow Jack and Geopolitics: Environment, Epidemics, and the Struggles for Empire in the American Tropics, 1640-1830. In: OAH Magazine of History 18 (3), pp. 9-13.

McNeill, John Robert (2010): Mosquito Empires. Ecology and War in the Greater Caribbean, 1620-1914. New York: Cambridge University Press (New Approaches to the Americas).

Moseley, Benjamin (1787): A Treatise on Tropical Diseases; and on the Climate of the West-Indies. London.

Nash, Linda (2014): Beyond Virgin Soils. Disease as Environmental History. In: Isenberg, Andrew C. (ed.): The Oxford Handbook of Environmental History. Oxford/New York/Auckland: Oxford University Press (Oxford Handbooks).

Osterhammel, Jürgen (2010): Die Verwandlung der Welt. Eine Geschichte des 19. Jahrhunderts. Lizenzausg. Bonn: bpb (Schriftenreihe/Bundeszentrale für Politische Bildung, 1044).

Peters, C. (1800): Two Sermons, Preached at Dominica, on the 11th and 13th of April, 1800, and officially Noticed by His Majesty's Privy Council in that Island. University of the West Indies, Cave Hill, WIC HT1071.P48.

Pinckard, George (1806): Notes on the West Indies: Written during the Expedition under the Command of the Late General Sir Ralph Abercromby; Including Observations on the Island of Barbadoes, and the Settlements Captured by the British Troops, upon the Coast of Guiana; Likewise Remarks Relating to the Creoles and Slaves of the Western Colonies, and the Indians of South America; With Occasional Hints, Regarding the Seasoning or Yellow Fever of Hot Climates. London.

SELECTIONS (1797 Feb 26). In: The Observer (1791-1900), 26 Feb. 1797, p. 2.

Seth, Suman (2018): Difference and Disease. Medicine, Race, and the EighteenthCentury British Empire. Cambridge: Cambridge University Press (Global Health Histories). 
Smyth, James Carmichael (1799): The Effect of the Nitrous Vapour, in Preventing and Destroying Contagion; Ascertained, from a Variety of Trials, Made Chiefly by Surgeons of His Majesty's Navy, in Prisons, Hospitals, and on Board of Ships: with an Introduction Respecting the Nature of the Contagion, which Gives Rise to the Jail or Hospital Fever; and the Various Methods Formerly Employed to Prevent or Destroy this. Philadelphia.

Speeches of Messrs. Thomson \& Borthwick, on the Question of Colonial Slavery, as Delivered in Dr. Wardlaw's Chapel, Glasgow (1833). National Records of Scotland, GD/142/57/4.

Stuchtey, Benedikt/Wiegeshoff, Andrea (2018): (In-)Securities across European Empires and Beyond. Mapping a New Research Field. In: Journal of Modern European History 16 (3), pp. 321-334.

The Fifth Report of the Board of Health; Containing Heads of Enquiry for Ascertaining what are Healthy Stations in the West Indies. Presented by the Board of Health to the Lords of His Majesty's Most Honourable Privy Council, London (1805), St. Vincent National Archives, CR-DESP-GA-76.

Turnbull, William (1806): The Naval Surgeon; Comprising the Entire Duties of Professional Men at Sea. To which are Subjoined, a System of Naval Surgery, and a Compendious Pharmacopoeia. London.

Vaughan, John (1794): b. West Indies and South America. iv. Windward and Leeward Islands. Commander-in-Chief, West Indies. Vaughan to Dundas 'Secret No 6'. Martinique. The National Archives (United Kingdom), WO 1/83.

West India Committee (1795), Standing Committee Minutes, The Alma Jordan Library, University of the West Indies, SC89.

Wheeler, Roxann (2000): Complexion of Race. Categories of Difference in Eighteenth-Century British Culture. Philadelphia: University of Pennsylvania Press (New Cultural Studies). 